\title{
К вопросу о заглублении раскрытых активных разломов в фундаменте Кольского полуострова
}

\author{
Никонов А.А. \\ Институт физики Земли РАН, Москва, nikonov@ifz.ru
}

\begin{abstract}
Аннотация. В статье сделана попытка собрать по разным группам признаков сведения об активности тектонических зон и идентифицируемых разломов/расколов в кристаллическом фундаменте на территории Кольского полуострова и частично в ограничивающих его водных бассейнах. Внимание сосредоточено на их верхних частях, где они проявляются в виде расколов-расщелений, полостей, фиксируемых разными современными способами. Речь идет о линейных нарушениях с признаками доледникового возникновения и последующей активизации в течение четвертичного периода, до средневековья. С этого времени теперь стало возможным фиксировать, и даже параметризовать, сейсмотектонические разрывы и сами сильные землетрясения прошлого. Рассматриваются более обеспеченные исходными материалами структурно-динамические новообразования вдоль Мурманского побережья на севере, Беломорского побережья - на юге, в срединной части Кольского полуострова - в Хибинском массиве и в Имандровской впадине. В современном наземном пространстве глубина расщеленных линейных новообразований измеряется первыми десятками метров, а в их подземных частях, в свободном и/или частично заполненном продуктами распада, глубина увеличивается на десятки метров, до 30-50 м, в сумме достигая 100 и более метров. В статье, помимо прояснения собственно геологической и ландшафтной обстановки, намечаются инженерно-геологическая, гидрологическая значимость и возможности выявления и параметризации сильных землетрясений прошлого.

Ключевые слова: Кольский полуостров, Мурманская зона, Хибинский массив, Белое море, ущелье, раскол, глубина расщеления, сейсмотектоника, сейсмодислокаци, сильные землетрясения.
\end{abstract}

\section{Revealed matters and new approach concerning to deep-rooted open clefts in crystalline basement of the Kola Peninsula region}

\author{
Nikonov A.A. \\ Schmidt Institute of the Physic of the Earth, Moscow,nikonov@ifz.ru
}

\begin{abstract}
In the article, an attempt is made to collect information on the activity of tectonic zones and identifiable faults in the crystalline basement on the territory of the Kola Peninsula and partially in the water basins, based on different groups of signs. Attention is focused on the upper parts, where they appear in the form of splits, clefts, crevices, fixed by various modern ways. We are talking about linear disturbances with signs of pre-glacial origin and later activation during the Quaternary period, up to the Middle Ages. Since that time, it has now become possible to record, and even parameterize, seismotectonic ruptures and the strong earthquakes themselves of the past. Structural-dynamic new formations, which are more abundant in initial materials, are considered along the Murmansk coast in the north, the White Sea coast in the south, in the middle part of the Kola Peninsula - in the Khibiny massif and in the Imandrovskaya depression. In modern terrestrial space, the depth of cleft linear neoplasms is measured in the first tens of meters, and in the underground open parts and / or partially filled with decay products, the depth increases by tens of meters, up to 30-50 m, reaching a total of 100 meters or more. In addition to the knowledge of the actual geological and landscape situation, the article outlines the engineering-geological, hydrological significance and outlines the possibilities of identifying and parametrizing strong earthquakes of the past.
\end{abstract}

Key words: Kola peninsula, Murman zone, Khibiny massif, White sea, ravine, split, deeprooted cleft, seismotectonics, seismodislocation, strong earthquake.

\section{Введение}

В многочисленных, разного времени и направленности исследованиях в отношении разломных структур нередко приводились факты и, соответственно, выводы об унаследованности позиции и простирания разломов новейшего и/или четвертичного времени древним, архейским и протерозойским в пределах северной части Фенноскандинавского кристаллического щита, в том числе в Швеции, Финляндии и на Кольском п-ове. Но вопросу о глубине проникновения в фундамент позд- 
нейших, активных разломов внимания почти не уделялось. Выяснение этого показателя разрывной тектоники по понятным причинам весьма затруднительно. Возможность такая появилась на отдельных, ограниченных, участках в местах глубоких котлованов, выемок и сосредоточенного бурения, но материалы, в большинстве, оставались в производственных отчетах проектных организаций. Автор давно старался собрать доступный, опубликованный материал (Никонов, 1968, 1969, 2010) и они рассматриваются здесь в пополненном виде. В основу положены сведения по открытым, с раздвинутыми бортами, разломам (расколам), в том числе с линейной корой выветривания и водонасыщением.

Для определения глубины проникновения разломов/расколов с раскрытием бортов в кристаллический фундамент использованы следующие признаки-критерии: 1) видимое надземное и скрытое подземное линейное расщеление, 2) глубина циркуляции подземных вод в расколе, 3) фиксация линейных зон раздробления скальных пород и пористого матрикса в вертикальных полосах (коры выветривания), 4) измерения видимой глубины скальных ущелий и разницы высот их бортов 5) учет глубинности днищ переуглубленных древних долин. К способам обнаружения такого рода признаков принадлежат наблюдения в крупных карьерах, горных выработках, на обнажениях, зондирование и геофизическое профилирование.

В коллективных докладах и публикациях последнего десятилетия приводились первичные материалы по расколам и разрывам в скальных породах фундамента в разных частях севера и центра Кольского региона (Никонов, Николаева, 2014; Никонов и др., 2015; Николаева и др., 2019).

\section{Скальные ущелья, расколы, расщеления}

На территории Кольского п-ова, особенно в его срединной части с горными массивами помимо неглубоких щелевидных нарушений в рельефе известны крупные ущелья в скальном субстрате, в горном массиве Хибин - ущелья Рамзая, Гакмана, Аку-Аку, безымянные ущелья на западном борту Имандровской впадины и в Чуна-тундре. Наземная их глубина составляет десятки метров, а, судя по углам падения стенок и ширине днищ в них, заполненные обломочным материалом нижние части уходят вниз на глубину 10-30-50 м. Суммарно определяется внедрение расколов в поверхность плакоров и некрутых склонов до 50-100 м. Теперь подобные новообразования стали известны (доклад на данной Конференции С.В. Шварева и А.О. Королевой). В большинстве случаев на тех же участках фиксируются сейсмотектонические и сейсмогравитационные деформации за счет сильных землетрясений прошлого (Николаева и др., 2018; Николаева и др., 2019; Никонов и др., 2019).

Вдоль северного побережья Кольского п-ова - крупнейшей Мурманской тектонической зоны шириной до первых десятков км (линеамент Карпинского) - на многих участках простираются узкие двубортные и односторонние частные грабены. На Западном Мурмане скальные щели в надповерхностных частях достигают глубины 50-60 и, должно быть, уходят в глубину еще на десятки метров (Никонов, Николаева, 2014; Никонов и др., 2015; Никонов, Флейфель, 2016; Никонов, 2018; Никонов и др., 2018; Николаева и др., 2019), а на Восточном они существенно меньше (Никонов, Зыков, 2017).

\section{Линейные коры выветривания}

В прежних работах по корам выветривания на Фенноскандинавском щите (Никонов, 1968, $1969,2010)$ на основе известной к тому времени зарубежной литературы с материалами по химическому выветриванию, было установлено, что в разных местах остатки каолиновой коры выветривания имеют предкембрийский и палеозойский возраст. Они встречены на йотнийских (Ptz) песчаниках на СВ борту Ботнического залива, в ЮЗ Норвегии, западнее оз. Венерн в Средней Швеции, под кембрийскими отложениями в ЮЗ Финляндии и севернее впадины Ладожского озера. На этой основе, с учетом равнинного, в общем, рельефа в этих местах автор признавал существование субкембрийского пенеплена. Понятно, что все выявленные периоды образования химической коры выветривания фиксируют субаэральные условия развития природной среды в районах находок. В ранней работе по корам выветривания на Кольском п-ове (Никонов, 1969) автор в отношении каолиновой коры выветривания пришел к выводу «о крупной эпохе континентального развития территории в условиях жаркого климата... она не могла сформироваться в четвертичный период и должна считаться доледниковой». 
Особого внимания заслуживает факт обнаружения в глубинной части акватории Белого моря, в его средине, в переотложенном состоянии меловых миоспор в трех грунтовых колонках (Дибнер, 1978, стр. 27-28). В Баренцевом море подобные микрофоссилии находили при бурении в разных местах. Но маловероятно, чтобы они могли быть занесены в глубину акватории из Баренцева моря через Горло Белого моря. Предполагается местное сильное погружение и перекрытие фундамента мезозойскими отложениями. Фундамент из рифейских песчаников опущен здесь на глубину до 3 км, тогда как в С3 части Кандалакшского грабена, и вблизи Архангельска на востоке выходит к поверхности. В самой глубинной части акватории, как теперь известно, в историческое время происходили сильные землетрясения, и при этом по бортам впадины не могла не происходить лавинная седиментация и, соответственно, перемешивание отложений.

\section{Скрытые расколы вдоль южного побережья Кольского n-ова}

Совершенно необычным, неизвестным ранее объектом в группе раскрытых разломных структур оказались крупные линейные полости в скальных породах вдоль северного берега Белого моря, «запечатанные» сверху моренными отложениями последнего оледенения. В 1986-1988 гг. детальными исследованиями, с бурением и геофизическим профилированием, в прибрежной полосе Беломорья вблизи устья р. Варзуга, обнаружены феноменальные расколы в осадочных протерозойских красных песчаниках (Икорский и др., 2014). Скважины бурились на глубину 100-300 м по 2-м профилям на всхолмленной равнине, частью болотистой. Сверху расколы оказались перекрыты четвертичными отложениями толщиной 7-10 м. Тем не менее, выяснилось, что по расселинам циркулирует воздух того же состава и с синхронными изменениями, как и на дневной поверхности. Грунтовые воды встречены на глубине 34 м от дневной поверхности, что, по-видимому, соответствует глубине проникновения в коренные породы раскрытых полостей. На участке бурения, в зоне древнего разлома в фундаменте, аномальная полоса с полостями прослежена на 5 км при ширине около 1 км. Но по расчетам объема циркулирующего в полостях воздуха объем полостей определен в 45-55 млн. $^{3}$, и зона повышенной пористости определяется протяженной в длину на 20-25 км.

Совершенно необычное по сущности и параметрам обнаружение системы вдольбереговых расколов имеет принципиальное значение для понимания размаха и свойств активной тектоники по северному борту крупнейшего Беломорского грабена. Это подтверждение его активности и косвенное указание на возможность подобных тектонических образований в самой акватории Белого моря. Представляется вероятным видеть в этом феномене уменьшенную (по размеру в 2 раза) модель разломов в осевой части акватории, простирающейся с С3 на ЮВ, с наибольшими глубинами до 300 м.

\section{Белое море, глубоководье}

Наличие в бассейне Белого моря, в его центральной части, линейной глубоководной, до 300 м глубины, впадины, совпадающей с простиранием оси всего бассейна, явление исключительной на всей территории Фенноскандинавского щита. Впадина, безусловно, тектонического происхождения, резко выделяющаяся на фоне общего, протерозойского Беломорского грабена, от Кандалакшского конца до Усть-Двинского. В настоящее время именно в этой глубинной части бассейна есть основания помещать эпицентральную часть сильнейшего из известных исторических землетрясений 1627 г., не только Российской части Фенноскандии, но и всего Фенноскандинавского щита.

Принципиально важные сведения по обсуждаемому объекту состоят в том, что при бурении в этом районе в кернах трех скважин, при микроскопическом изучении были обнаружены миоспоры миоценового возраста. Указанный факт ведет к заключению о том, что впадина как особая, наложенная отрицательная тектоническая структура с размахом сотни метров начала формироваться не позже миоцена, 13-11 млн. л.н. Ни в одном другом месте восточной части Фенноскандинавского щита подобные определения не известны. Это, своего рода, феномен важнейшей значимости, поскольку обнаружена активность сейсмоструктуры за последние 500 лет. 


\section{Погребенные долины}

Характеристика древних, переуглубленных, долин на Кольском п-ове представлена автором полвека назад по материалам проектно изыскательских работ под гидроэнергетические сооружения (Никонов, 1967). Их глубина определялась величиной 70-120 м от исходной, плоской поверхности материка. Выработка долин с крутыми уклонами русел и с крутыми бортами в скальных породах не объясняется только длительностью континентального, предледникового, развития региона и русловой эрозией. Особенно, принимая во внимание, что глубина русел послесреднечетвертичного периода и в коренных породах, в ущельях, как в долине р. Вороней, и в четвертичных отложениях, как в долине р. Туломы, составила только около 40 м. Такая разноразмерность не может быть объяснена климатическими различиями разных эпох, поскольку только в периоды дегляциации, т.е. в краткие периоды сезонного бушевания талых вод, их масса и скорость течения становились на порядки выше обычных. Объяснение реалистичное состоит в принятии использования водными потоками в доледниковье (в третичный период), и в безледные и без высокого уровня приемных морских бассейнов плейстоцена, ослабленных разломных тектонических зон, открытых и частично заполненных раздробленным скальным материалом и/или корой выветривания. Как теперь устанавливается, в Фенноскандии, в первую очередь в Северной, древние разломы оживлялись особенно при дегляциации и оживляются до сих пор при мощных землетрясениях, с расщелениями и смещениями бортов при $\mathrm{M} \geq 6$. Отсюда резонно заключить, что разломы с зонами дробления в рассматриваемом Кольском регионе, в породах архея и протерозоя, проникали вглубь не только на десятки, но и на $\geq 100$ м. Автор не имел возможности работать с первичными материалами производственных и проектных организаций на хорошо разбуренных участках. Поэтому остался неосвещенным вопрос о глубине проникновения и трещин с сомкнутыми бортами. Но и доступные определения заглублеия расколов с сомкнутыми бортами важны, поскольку теперь все больше выясняется, что наличие и характер таковых дает возможность фиксировать и параметризовать сильные землетрясения прошлого в соответствующих локалитетах.

Помимо познания собственно геологической и ландшафтной обстановок намечаются инженерно-геологическая, гидрологическая значимость выявляемых фактов, а также весьма актуальная возможность выявления и параметризации сильных землетрясений прошлого.

\section{Благодарности}

Автор признателен Л.Д. Флейфель за помощь в подготовке статьи.

Работа выполнена в рамках Госзадания № 0144-2019-0010.

\section{Литература}

1. Дибнер В.Д. Морфоструктура шельфа Баренцева моря. Л. Изд-во: Недра. 1978. 211 с.

2. Икорский С.В., Калинкин М.М., Куваева Н.М., Нивин ВА., Припачкин В.А., Пушкин М.Г. Эффект «подземного ветра» на Кольском полуострове // Тиетта. 2014. № 2. С. 7-11.

3. Николаева С.Б., Никонов А.А., Шварев С.В. Поздне- и послеледниковые разломы и палеосейсмонарушения в восточной части Фенноскандинавского щита: обзор и результаты исследований // Труды Ферсмановской научной сессии ГИ КНЦ РАН. 2019. № 16. С. 428-432. DOI: 10.31241/FNS.2019.16.087.

4. Николаева С.Б., Никонов А.А., Шварев С.В., Родкин М.В. Детальные палеосейсмогеологические исследования в бортовой зоне впадины оз. Имандра (Кольский регион): новые подходы и результаты // Геология и геофизика. 2018. Т. 59. № 6. С. 866-880. DOI: 10.15372/GiG20180608.

5. Никонов А.А., Зыков Д.С., Николаева С.Б., Шварев С.В. Шовная зона «Линия Карпинского» на севере Европы как активный тектонически и сейсмически сейсмолинеамент высшего порядка // Проблемы тектоники и геодинамики земной коры и мантии. Материалы L Тектонического совещания. T. 2. M. Изд-во: ГЕОС. 2018 С. 53-56.

6. Никонов А.А. О древних долинах северо-восточной части Балтийского щита // Доклады АН СССР. 1967. Т. 177. № 5. С. 1155-1158.

7. Никонов А.А. Коры выветривания Фенноскандии, их возраст и палеогеографическое значение // Бюлл. МОИП. Отд. геол. 1968. Т. 43. Вып. 5. С. 108-118. 
8. Никонов А.А. О коре выветривания Кольского полуострова // Изв. АН СССР. Сер. геогр. 1969. № 2. C. 101-106.

9. Никонов А.А. Коры выветривания Фенноскандии и их размыв как показатели развития северного материка в мезокайнозое // Труды Всероссийского совещания «Россыпные месторождения и коры выветривания». Новосибирск. 2010. С. 509-513.

10. Никонов А.А. Молодые продольные расколы в морфоструктуре Мурманской зоны разломов // Труды Ферсмановской научной сессии ГИ КНЦ РАН. 2018. № 15. С. 263-267. DOI 10.31241/FNS.2018.15.065.

11. Никонов А.А., Зыков Д.С. О признаках мощных землетрясений в восточном секторе Мурманской зоны (линия Карпинского) // Труды XIV Ферсмановской научной сессии. Апатиты. 2017. С. 143-148.

12. Никонов А.А., Николаева С.Б. Линеамент Карпинского на границе Фенноскандинавского кристаллического щита и Баренцевой плиты как активная тектоническая и сейсмическая зона // Комплексные исследования природы Шпицбергена и прилегающего шельфа: Матер. Межд. научной конфер. Вып. 12. М. Изд-во: ГЕОС. 2014. С. 232-237.

13. Никонов А.А. Флейфель Л.Д. Тектонические деформации в рифейско-вендских отложениях на северовостоке п-ова Средний (южная ветвь линии Карпинского) // Труды XIII Всероссийской Ферсмановской научной сессии. Апатиты. 2016. С. 114-118.

14. Никонов А.А., Шварев С.В., Николаева С.Б. Мурманское побережье - крупнейшая в Российской Арктике сейсмогенерирующая зона: новейшие разработки // Природные ресурсы и комплексное освоение прибрежный районов Арктической зоны. Сб. научных трудов. Архангельск. 2015. С. 34-40.

15. Никонов А.А., Шварев С.В., Николаева С.Б., Зыков Д.С., Флейфель Л.Д., Родкин М.В., Королева А.О. // Три активные сейсмотектонические зоны высшего ранга на севере Европейской части России: прогресс-репорт. Проблемы тектоники континентов и океанов. Материалы LI тектонического совещания. М. Изд-во: ГЕОС. 2019. Т. 2. С. 86-92. 